\title{
Chironomids: A Personal Journey
}

\author{
Carlos L. de la Rosa
}

Organization for Tropical Studies, La Selva Research Station, P.O. Box 676-2050, San Pedro, Costa Rica E-mail: carlos.delarosa@,tropicalstudies.org

The year was 1977. I was an undergraduate student at the newly created Biology Department at the Simón Bolívar University in Venezuela. We were a group of about 30 students, mostly transfers from other careers (I had been in Engineering for 3 years when I transferred to Biology), who had waited patiently for the bureaucratic process of creating a new department in our university. A team of new faculty members, some very well known scientists, some barely older than we were, worked with the students to create the new curriculum, outfit the laboratories, and develop research projects where the students could participate as research assistants. It was a wonderful time filled with creativity, endless energy, hard work, and fantastic scholarship and idealism. Some of us students drifted from lab to lab, learning techniques, going on field trips with our professors, and learning the ropes of this new career we had chosen: to be a professional biologist.

This particular summer I was working in the aquatic biology lab, run by the Academic Coordinator of the department, Dr. Roger Carrillo. Roger had recently returned from his Ph.D. degree in aquatic ecology at the University of Pittsburgh, under Dr. William Coffman. Roger invited Bill to visit him in Venezuela, go collecting in a few places, and give a talk at the department. Bill gave a presentation on his research on Chironomidae, in English of course, which most of us understood only a little. In spite of the language barrier, I was fascinated by his work and hoped to have a chance to meet him later at the lab and show him my samples. I had been collecting midges in Lake Valencia, an endorheic lake in north-central Venezuela. I collected a wide range of aquatic insects and struggled with the lack of field guides to identify the creatures. Particularly vexing was the collection of Chironomidae. I had many larvae that I could tell were probably different species, but I had no way to get them further identified. The only books available to me were old copies of Pennak (1953) and Edmondson (1959) and the recently-published Spanish version of Needham and Needham (1978), all of which had proven useful to identify things to order or family, but not beyond. Bill came to the lab that afternoon and I showed him a dish filled with chironomid larvae. He looked through the microscope and started sorting the larvae into three groups. Pointing with his forceps to one group he said, (and Roger translated to me): "This group are probably new species. I can recognize the genera, but they are likely new. This other group," he said while pointing at the second little pile of larvae, "I can't recognize the genera. I'm sure they are totally new." And finally, pointing to the third and smaller pile, he added excitedly, "And this last group. Well, these are unique and bizarre. I can't even put them to subfamily!"

At that moment, something clicked in my mind. The demonstration and seeing his enthusiasm, his passion for the midges, left me speechless. My thought was "This is exactly what I want to do with my life." I wanted to be able to do what he had just done, look into a dish of creatures and know what they were and what they were not and what to do about them. From that day on, all my energy became focused in getting accepted at the University of Pittsburgh to study under Coffman. For the next fourteen years or so I spent most of my time studying midges to get my $\mathrm{Ph} . \mathrm{D}$. and later collecting in Costa Rica and Florida

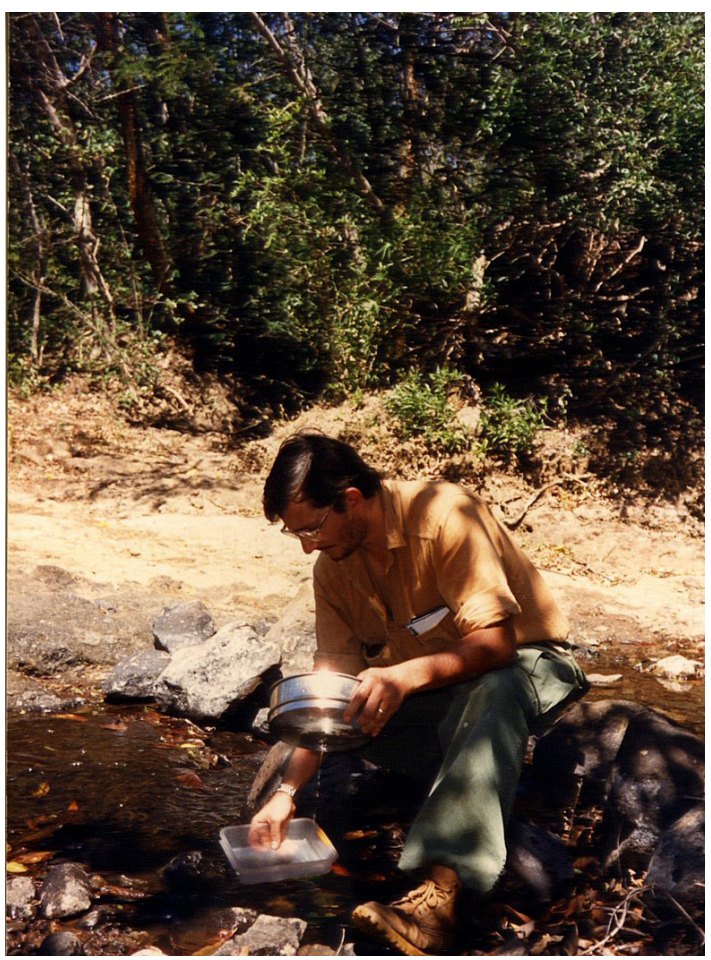

Figure 1. Carlos de la Rosa collecting chironomid pupal exuviae in Costa Rica, 1989. in collaboration with Bill (Fig. 1). 
Now, move forward 38 years to today. My career has taken many turns, some of them a bit odd but all interesting and productive. But all throughout these decades, midges have always been part of my life. I have not worked steadily in taxonomy or ecology of the family, and my publications on them or that include the family are very few (de la Rosa, 1985, 1997, 1992, 1996, 1997a,b, 2002, 2013, 2014; de la Rosa and Nastase, 1987; Coffman, Yurasits and de la Rosa, 1988; de la Rosa and Barbee, 1993, 1995; Epler and de la Rosa, 1995; Nastase, de la Rosa and Newell, 1995; Coffman, de la Rosa, Cummins and Wilzbach, 1992; de la Rosa, Koebel and Cummins, 1998; Coffman and de la Rosa, 1998). However, regardless of the job I had at any given time, I continued to collect midges when I could, particularly tens of thousands of specimens of pupal exuviae, in Venezuela, Pennsylvania, Florida and Costa Rica, all of which ended up in Bill's extraordinary collection of over 100,000 specimens. Bill even made a trip to Costa Rica and we collected in 26 different streams, rivers and lakes around the country (Fig. 2). This collection is now being maintained, curated and expanded at the La Selva Research Station of the Organization for Tropical Studies in Costa Rica, thanks to the generosity and expediency of a number of people that allowed us to rescue the collection and save it from a possible loss after Bill's death in 2012 (de la Rosa, 2012; Levin, 2013). Through all those years, I worried over the fate of all this extraordinary material, mounted and prepared with exquisite care, cataloged, illustrated and identified by Bill but never published. The collection and catalogs hold over 450 undescribed pupal exuviae from Venezuela, Trinidad and Costa Rica, most of which will end up being new species to science (Fig. 3). Who is going to be able to work on this material and how are we going to make it work for science and society?

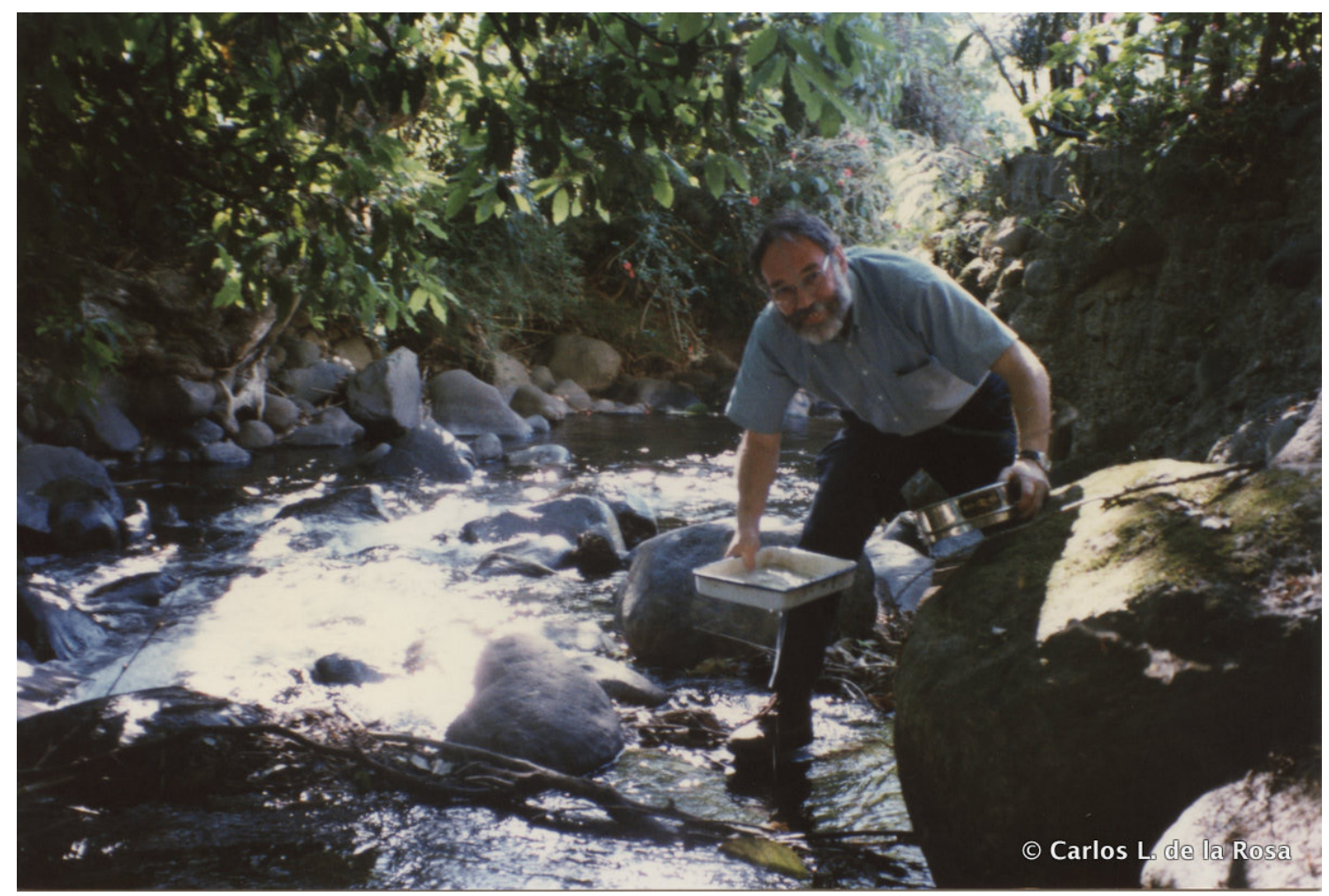

Figure 2. William Coffman collecting pupal exuviae in Costa Rica, February 1997.

There is a complex set of circumstances and challenges that have made this an important part of my past and current work. I have always felt that we should describe all of Bill's pupal exuviae types as proper species, using the pupal exuviae as the taxonomically significant life stage. My arguments have been: (1) they are easily collected, preserved, mounted and identified, characteristics that make them accessible to biologists in developing countries; (2) most aquatic biologists would welcome the opportunity to use exuviae as a survey tool for examining their communities, especially in the tropics where relatively little is known about this group, but only if they could identify them; (3) the collection of pupal exuviae causes minimal to no impact to the aquatic communities, in contrast to benthic sampling. This is an important consideration in fragile ecosystems and in protected areas; (4) the immediate problems with synonymy would be relatively small compared with the enormous value of having the fauna described and named as pupae. To date we have about 90 chironomid species recorded for Costa Rica (Epler, personal communication), 
most of which have only been described as adults. Additionally, a new study in a small area of northcentral Costa Rica has produced over 100 new species and records for the country (Epler, personal communication). Bill estimated there were at least 1,000 species in Costa Rica, although that number could be still higher. The possible synonymy issues could be resolved over time; and (5) the availability of keys and descriptions for pupal exuviae would galvanize the necessary work of obtaining associations through rearing larvae to adults. As you can imagine, this proposal never received much support, either from Bill or from the other chironomid taxonomists I spoke to about it. The most common response I received from my taxonomy colleagues was "Get associated material! It is the only way." So the dilemma lingered.

In the last two years (2014-2015) I have been working with two extraordinary parataxonomists (see Janzen et al., 1993 for the definition of what a parataxonomist does), several volunteers, and a few generous scientists in obtaining additional pupal exuviae material from Costa Rica (Fig. 4), focusing on areas that had not been collected during my previous tenure in this country from 1987 to 1997 . We have accumulated so far several hundred samples from 78 separate freshwater ecosystems, including bi-weekly year series from 8 streams and rivers. More importantly, we have obtained over 700 associations of larvae-pupaeadult or pupae-adult (plus a few larvae-pupae that failed to emerge), and we get more every day (Figs. 5 and 6). With this new material, the Coffman collection is likely to become (if it is not already) the most comprehensive and complete chironomid collection from a Central American country, and likely from Latin America.

New technologies, such as DNA barcoding applied to pupal exuviae and chironomids in general (see Ekrem and Stur, 2007; Ekrem et al., 2010; Stur and Ekrem, 2011; Anderson et al, 2013; and Kranzfelder et al., 2015, as examples) also promise to increase exponentially the number of correctly associated material without having to rear them from larvae, as well as open a huge opportunity to correctly identify species using DNA from pupal exuviae (Krosch and Cranston, 2012). Additionally, the use of chironomid pupal exuviae sampling in tropical environments has received a strong boost from recently published papers (Kranzfelder et al., 2015b; Kranzfelder and Ferrington, 2015; and the very interesting Kranzfelder et. al., 2015a which uses video to present their techniques). These and other papers forthcoming in Spanish will facilitate access to proper techniques, protocols, applications and, eventually, keys to the many genera and species that live in this huge bioregion to an underrepresented but eager audience of Latin American scientists and students.

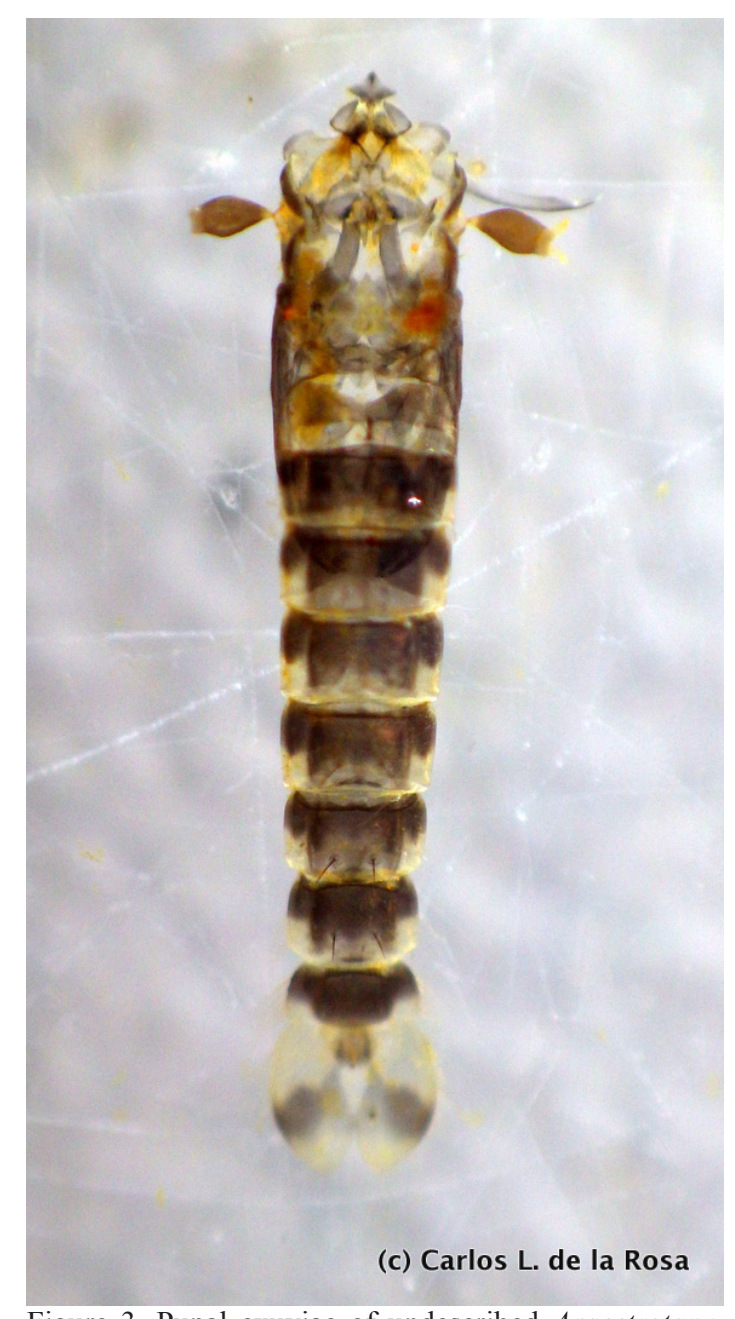

Figure 3. Pupal exuviae of undescribed Apsectrotanypus.

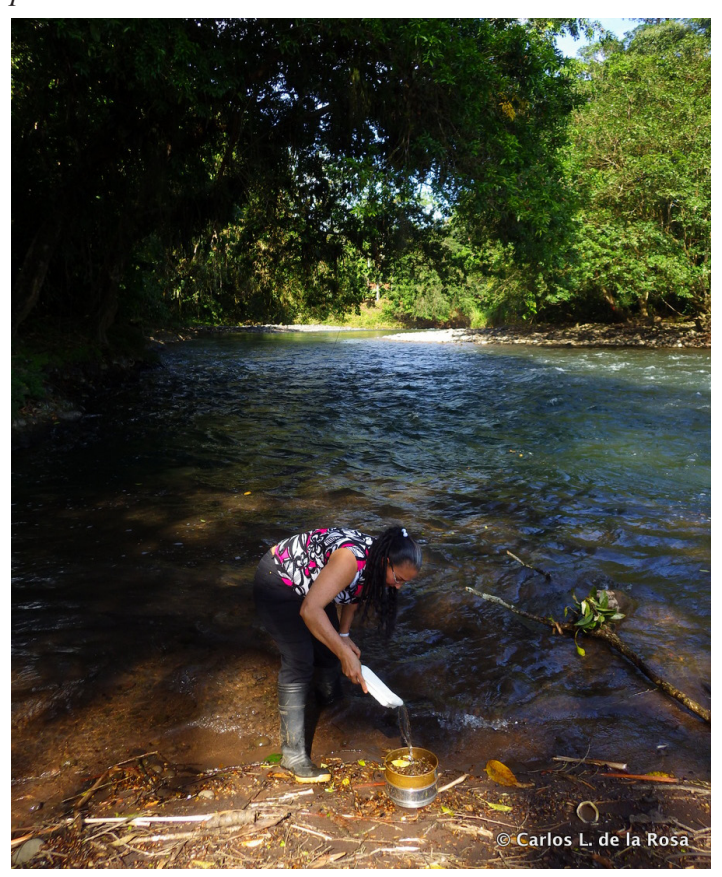

Figure 4. Socorro Avila, parataxonomist, collecting larvae and pupal exuviae in the Sarapiquí River, April 2015. 
I feel that we are on the threshold of a tropical chironomid taxonomy revolution, one where a new generation of aquatic biologists and taxonomists-intraining, together with parataxonomists and the international chironomid expert community, can take a giant leap forward in placing chironomids in their proper place in studies of aquatic ecosystems, especially in the Neotropics where many aquatic ecosystems are under severe threat. The interest in effective, minimally destructive, and useful monitoring techniques is rapidly increasing, as Latin America faces the challenge of hasty development and its accompanying destruction of aquatic and riparian ecosystems. Rivers and streams are too often seen as resources to be exploited for drinking water, irrigation, transportation, generation of electricity, aquaculture, and even waste disposal. Most studies of the environmental impact of industry never consider the rivers as true ecosystems, filled with unique species assemblages and communities, fragile and in need of protection and management.

And here is where the international chironomid community can play an important role. Supporting the local inventories, the training of Latin American technicians (e.g., Ekrem et al., 2013), biologists and taxonomists, collaborating in projects, and helping secure funds for processing and describing the materials collected, will be key for building a genuine capacity in developing countries like Costa Rica to pursue sustainability, ecosystem viability and conservation goals. I hope you join the effort.

\section{Acknowledgements}

There are truly too many people I should thank for their support over the years in this work. First and foremost, Roger Carrillo-Castellanos and William P. Coffman facilitated my first introduction to chironomids and supported my early forays in the family. Coffman in particular is the reason why I have stuck with this dream for so long, and his specimens, drawings and notes continue to inspire and motivate me.

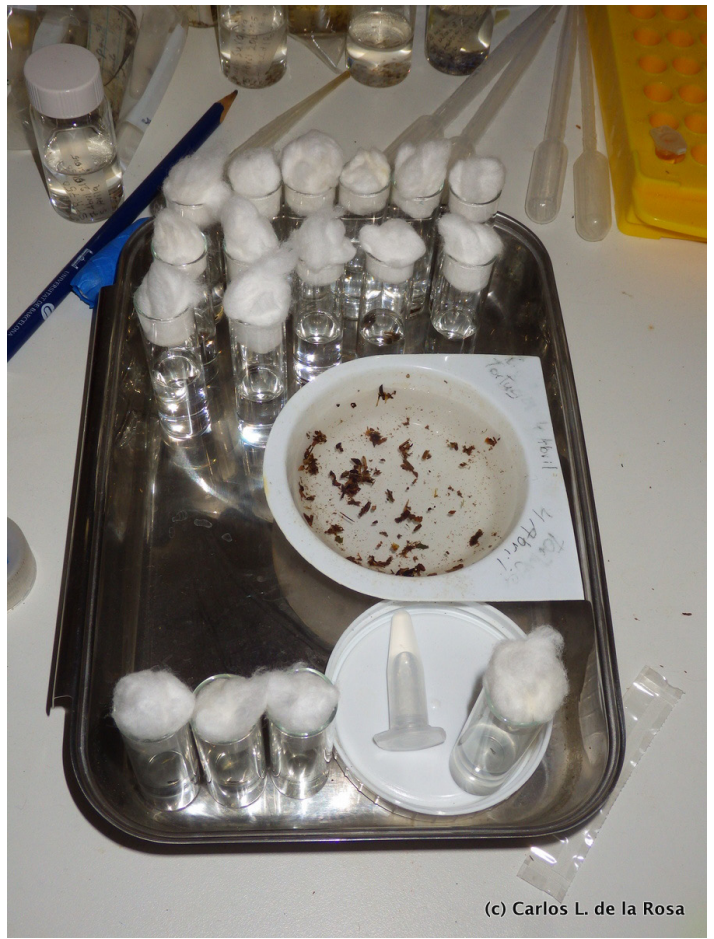

Figure 5. Chironomid rearing setup at the Coffman Laboratory of Aquatic Entomology, at the La Selva Biological Station, Costa Rica.

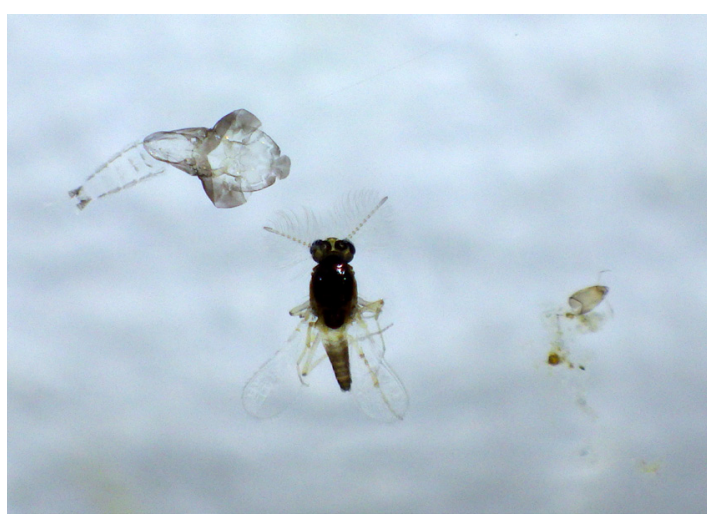

Figure 6. Association of larvae, pupae and adult of undescribed Corynoneura.

The Pymatuning Laboratory of Ecology, University of Pittsburgh, under the direction of Richard T. Hartman (1973 to 1987) provided special support to my early career. John Epler has been a long-term source of inspiration and support. Rick Jacobsen has also been an important player in bringing the collection to Costa Rica and in preparing and patiently waiting for the research funding to come. Walter Carson, Lou Yurasits and the administrative leadership of the University of Pittsburgh's Department of Biological Sciences for smoothing the way for Bill's collection to find a suitable home before his untimely death. Tørbjorn Ekrem and Elisabeth Stur for their amazing work on DNA, for including Latin America as an important area of their work, and for providing incentives and personal effort in the training of Latin American biologists in DNA barcoding techniques. Finally, I'd like to thank Martin Berg, Broughton Caldwell, Len Ferrington, Petra Kranzfelder, Alyssa Anderson, Bohdan Bilyj, and many others I may forget, for their contributions and reviews of manuscripts.

\section{References}

Anderson A. M., Stur, E. and Ekrem, T. 2013. Molecular and morphological methods reveal cryptic diver- 
sity and three new species of Nearctic Micropsectra (Diptera: Chironomidae). - Freshwater Science 32(3): 892-921.

Coffman, W.P., Yurasits, L.A. and de la Rosa, C. 1988. Biogeography of the family Chironomidae of India, with description of two strange pupal exuviae. - Spixiana Supplement 14: 155-165.

Coffman, W.P. and de la Rosa, C.L. 1998. Taxonomic composition and temporal organization of tropical and temperate species assemblages of lotic Chironomidae. - Journal of the Kansas Entomological Society 71(4): 388-406.

Coffman, W.P., de la Rosa, C., Cummins, K.W. and Wilzbach, M.A. 1992. Species richness in some Neotropical (Costa Rica) and Afrotropical (West Africa) lotic communities of Chironomidae (Diptera). Netherlands J Aquatic Ecol 26: 229-237.

de la Rosa, C. 1985. Resource utilization by Chironomidae (Diptera) in a woodland stream ecosystem, Linesville Creek, Crawford County, Pennsylvania. Ph.D. dissertation, U. of Pittsburgh, Pgh, PA.

de la Rosa, C. 1992. Phoretic associations of Chironomidae (Diptera) on Corydalidae (Megaloptera) in northwestern Costa Rican streams. - Journal of the North American Benthological Society 11(3): 316323.

de la Rosa, C. 1997. Chironomidae. In: Solís, A. (ed.) Las Familias de insectos de Costa Rica. INBio. http:// www.inbio.ac.cr/papers/insectoscr/Texto197.html

de la Rosa, C. 1997. A guide to common aquatic organisms of the Kissimmee River. Riverwoods Field Laboratory, Special Publications of the Center for Environmental Studies, Florida Atlantic University, Palm Beach Gardens, Florida.

de la Rosa, C. and Barbee, N. 1993. Guía de los Organismos Comunes de las Aguas Dulces de Costa Rica. Special Publications of the Environmental Management Office, USAID, Costa Rica.

de la Rosa, C. 1995. Middle American Streams and Rivers. In: Cushing, C.E., Cummins, K.W. and Minshall, G.W. (Eds.) Rivers and Stream Ecosystems, Series Ecosystems of the World, Vol 22, Elsevier Science Publishers, pp. 189-218.

de la Rosa, C. 1995. Chironomidae. In: Solís, A (Ed.) Guía para las Familias de Insectos de Costa Rica, Special Publications of the Instituto Nacional de Biodiversidad (INBio), San José, Costa Rica. Available in electronic form only.

de la Rosa, C. 1996. Los Quironómidos de Costa Rica. Contribuciones del Departamento de Historia Natural, Museo Nacional, San José, Costa Rica.

de la Rosa, C. 1999. Conservation and sustainable use of streams and rivers in Central America. In: Hatch, U. and Swisher, M. (Eds.) Managed Ecosystems: The Mesoamerican Experience, Oxford University Press, pp. 304-325.

de la Rosa, C. 2002. A Guide to the Aquatic Invertebrates of South Florida, Vol. 1: Wetlands. Multi-media publication. LDP Productions, Florida.

de la Rosa, C. 2012. Dr. William P. Coffman: Celebrating 50 Years of Research on Chironomidae. - Chironomus Newsletter on Chironomidae Research 25: 4-8.

de la Rosa, C. L. 2013. The Year of the Midge: Chironomids coming to age in Costa Rica. New Frontiers in Tropical Biology: The Next 50 Years (A Joint Meeting of ATBC and OTS), Symposium Tropical Stream Ecology: Research Needs in a Changing Planet.

de la Rosa, C.L. 2014. ¿Cuántas especies hay todavía por descubrir? - BIOMA 15: 19-27.

de la Rosa, C. and Nastase, A. J. 1987. Larvae of Metriocnemus c.f. fuscipes, Limnophyes sp. Pentaneurinae (Diptera, Chironomidae), and Culicoides (Diptera, Ceratopogonidae) from pitcher plants, Sarracenia purpurea. - Journal of the Kansas Entomological Society 60(2): 339-341.

de la Rosa, C. L. and de la Rosa, C. A. 2001. A Guide to the Aquatic Organisms of the Loxahatchee River Basin, multi-media publication, City of West Palm Beach, Florida.

de la Rosa, C. and Barbee, N. 1995. Protocolos de Bioevaluación Rápida (PBR) para ríos y arroyos tropi- 
cales: Macroinvertebrados. FIREMA Environmental Education Press, Upala, Costa Rica.

de la Rosa, C., Koebel, J.W. and Cummins, K.W. 1998. Restauración de Ecosistemas Acuáticos: la Cuenca del Río Kissimmee en Florida (Restoration of Aquatic Ecosystems: The Kissimmee River Basin in Florida). Keynote address. Proceedings of the Fourth Interamerican Congress on the Environment (CIMA 1997). Caracas, Venezuela.

Edmondson, W.T. (Ed.) 1959. Fresh-water biology, Second Edition. John Wiley \& Sons, Inc., London, $1248 \mathrm{p}$.

Ekrem, T., Willassen, E. and Stur, E. 2007. A comprehensive DNA sequence library is essential for identification with DNA barcodes. - Molecular Phylogenetics and Evolution 43(2): 530-542.

Ekrem, T., Willassen, E. and Stur, E. 2010. Phylogenetic utility of five genes for dipteran phylogeny: A test case in the Chironomidae leads to generic synonymies. - Molecular Phylogenetics and Evolution 57(2): $561-571$.

Ekrem, T., Stur, E. and de la Rosa, C. 2013. First Workshop on DNA Barcoding applied to Aquatic Invertebrates. Natural History and Archaeology Museum, Norwegian University of Science and Technology, and La Selva Biological Station, Organization for Tropical Studies, Costa Rica. 27-29 Aug 2013.

Epler, J. H. and de la Rosa, C. 1995. Tempisquitoneura, a new genus of Neotropical Orthocladiinae (Diptera: Chironomidae) symphoretic on Corydalus (Megaloptera: Corydalidae). - Journal of the North American Benthological Society 14(1): 50-60.

Janzen, D.H., Hallwachs, W., Jiménez, J., Gámez, R. 1993. The role of the parataxonomists, inventory managers, and taxonomists in Costa Rica's national biodiversity inventory. In: Reid, W.V., Laird, S.A., Meyer, C.A., Gámez, R., Sittenfeld, A., Janzen, D.H., Gollin, M.A., Juma, C. (Eds) Biodiversity prospecting: using genetic resources for sustainable development. CAB 1993 pp. 223-254.

Kranzfelder, P., Anderson, A.M., Egan, A.T., Mazack, J.E. Bouchard Jr., R.W. Rufer, M.M. and Ferrington Jr., L.C. 2015a. Use of Chironomidae (Diptera) surface-floating pupal exuviae as a rapid bioassessment protocol for water bodies. - Journal of Visual Experiments (101), e52558, doi:10.3791/52558.

Kranzfelder, P., Ekrem, T. and Stur, E. 2015b. Trace DNA from insect skins: a comparison of five extraction protocols and direct PCR on chironomid pupal exuviae. - Molecular Ecology Resources DOI: 10.1111/1755-0998.12446.

Kranzfelder, P. and Ferrington, L.C. 2015. Characterization of Chironomidae (Diptera) surface-floating pupal exuviae sample sort time from coastal tropical aquatic systems. - Environmental Monitoring and Assessments 187:70 DOI 10.1007/s10661-015-4313-0.

Krosch, M.N. and Cranston, P.S. 2012. Non-destructive DNA extraction from Chironomidae, including of fragile pupal exuviae, extends analysable collections and enhances vouchering. - Chironomus Newsletter on Chironomidae Research 25: 22-27.

Levin, S. 2013. A Season of Midges. - PITT Magazine Winter 2013: 31-34.

Nastase, A., de la Rosa, C. and Newell, S. 1991. A comparison of three methods for collecting dipteran insect which inhabit the northern pitcher plant (Sarracenia purpurea). - American Midland Naturalist 125: 356-35.

Nastase, A.J., de la Rosa, C. and Newell, S.J. 1995. Abundance of pitcher-plant mosquitoes, Wyeomyia smithii (coq.) (Diptera: Culicidae) and midges, Metriocnemus knabi Coq. (Diptera: Chironomidae), in relation to pitcher characteristics of Sarracenia purpurea L. - American Midland Naturalist 133: 44-51.

Needham, J.G. and Needham, P.R. 1978. Guía para el studio de los seres vivos de las aguas dulces. Ed. Reverté, S. A. Barcelona. 131 p.

Pennak, R.W., 1953. Fresh-water invertebrates of the United States. The Ronald Press Company, New York. 769 p.

Stur, E. and Ekrem, T. 2011. Exploring unknown life stages of Arctic Tanytarsini (Diptera: Chironomidae) with DNA barcoding. - Zootaxa 2743: 27-39. 